\title{
Transformations of traditional architectural heritage on the case study of mahala Svirac in Gradačac
}

\author{
L. Kudumović \& A. Idrizbegović Zgonić \\ Faculty of Architecture, Sarajevo, Bosnia and Herzegovina
}

\begin{abstract}
Old historic residential areas represent a cross section of information on cultural, social and economic circumstances of their time. Through various periods, adaptation and transformation led to the loss of material identity of mahalas (residential/neighborhood areas from the ottoman period) as living blocks of old cities. Mahalas had universal humanistic values, followed the basic principles of human life (a view and sunlight), respected the site, neighborhood, and value of their surroundings etc. Over time, man has adapted the houses to his contemporary needs and lifestyle, which was inevitable, but on the other hand as a result of these interventions irreversible changes have appeared. Analyzing the processes of reversibility/irreversibility through a case study of vernacular architecture of mahalas, we will raise the issues of recognizing the loss and modes of dealing with it today. The objectives of this study are: defining the historic environment, the importance and value of mahalas in general; defining characteristics of Gradačac mahala Svirac; and identifying the degree of degradation of mahala Svirac through the presence of irreversible phenomena of new construction. One should try to simulate a new image of the city, taking into account changes of life styles based on social and economic thinking. The mahala, as an integral part of the city, should be a sustainable structure based on created and inherited values that we already have, but also taking into consideration the contemporary circumstances of life and innovative architectural and urban improvement solutions. Historic residential areas require a legal and active protection.
\end{abstract}

Keywords: residential areas, degradation, irreversible changes, reversible processes. 


\section{Introduction}

Cultural heritage as an identity factor has been defined as a feature of crucial importance through time. Most of the meaning comes from the non-material heritage, but with an accelerated physical deterioration, the main issues are recognizing and dealing with the irreversible loss of architectural tissue. Complex historical circumstances and surprisingly simple forms have created an expressive architecture, highly adapted to local morphology, climate and lifestyle. The traditional housing complex from the Ottoman period was an elaborate product of local processes, material and metaphysical aspects of its time. New infill and inadequate interventions resulted in a degradation of the heritage, especially in the last 20 years, where it is prevalent in most of the cities. One of them is the case study of this paper just as an indicator of the process that is very aggressive and ongoing in the entire country, and for the time being the public and architects have not been fast or effective enough with a response. Mahala no longer exist in its original form as part of town with living functions and traditional architecture. As the number of such dwellings grows the traditional tissue is disappearing thus distorting the memory of place, where people identify with the new architecture.

Residential areas represent a system, and must be viewed as a system during any building action in its context or environment.

In speaking about the qualities of mahala quarters we should refer primarily to the quality of living in such an environment. Today it can be seen from the aspect of humanity, social life, human relations, ecology, healthy living and old quarters had all these characteristics. The old parts of towns are constantly under pressure of new construction. This issue is addressed without creativity, or an integral approach and evaluation. The overall urban scale and concept of Bosnian mahala has disappeared. Some preserved buildings are isolated but important to give guidance for future architectural design.

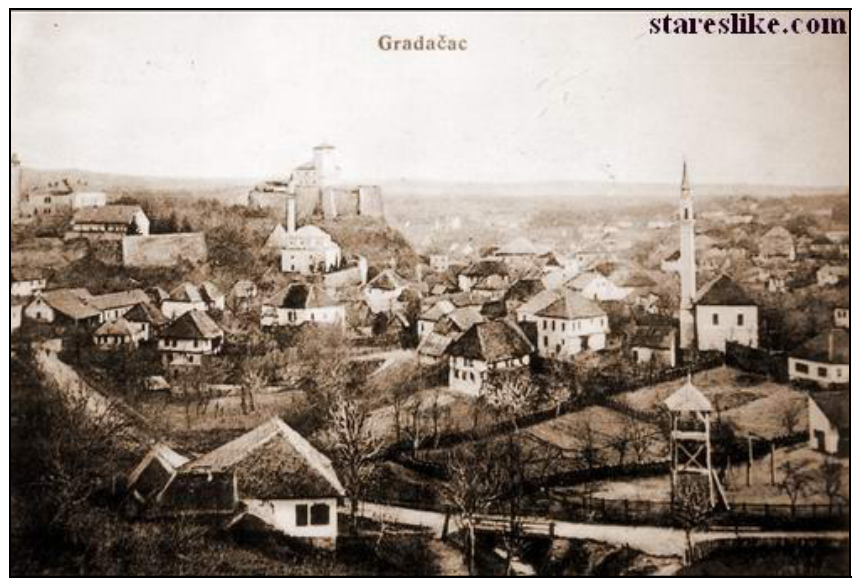

Figure 1: Historic view of Gradacac showing the urban and architectural composition of the city. 


\section{The argument}

The loss of historic tissue is evident, and changes are irreversible and we should not insist on the old fashioned preservation concepts that have become unsustainable and do not follow the pace of transformation. We must recognize and evaluate the present situation, but also reverse the negative trends and processes into improvement of urban areas and architectural solutions.

\section{Definitions of residential complexes}

Development of settlements in Bosnia and Herzegovina mostly began in the Ottoman period in the XVI century, forming trading centers at the crossroads of major roads along the rivers, roads and routes. During this period residential quarters and urban districts were built intended solely for housing. Each city had a craft town market, or the bazaar, and the part for housing a mahala [1]. Adjacent structures like mosques, han, schools and baths are built in the settlement. Usually simple structures formed the bazaar, the craft, and trade shops [2]. The residential zone is built around the market-place, with forty to fifty residential complexes or houses. Mahalas, as symbols of national architectural heritage, carry their values in urban concept and strikingly simple cubic architectural forms configured according to the morphology and climate of the place. Houses are built usually on sloped terrain with the provision of a free viewpoint, and the integration of nature within the walls of the complex that provide privacy.

There are main streets in urban patterns and blind "Čikma" (alleyways) leading to individual houses. The houses themselves are part of the system and the environment, woven into an inestimable value and uniqueness. Each has a custom field, and climatic conditions, but what is common to all types of Bosnian houses is that they respect the basic principles of construction scale and for man. Development of a house in the Bosnian quarters means adapting to climate, field and other areas where conditions are developed. In Bosnia and Hercegovina we can recognize the basic types of traditional houses with typical elements. Numerous references analyzed the Bosnian house and types of housing from rural to urban. The differences that arise among the types of houses are the result of human activity. They have been adapted to various physical and spiritual needs, such as the division of rooms in houses built on the basis of domestic regulations and life. It is especially important now to look, analyze and find parameters of a positive life in its full force.

Figure 2 shows a map of Gradačac municipality made in 1882 by the Austrian authorities for military service and taxation purposes. This was crucial since these records are sometimes used even today, and changes on the ground are not continuously monitored or plans registered, so that today state plans are different from the situation on the ground. 
348 Structural Repairs and Maintenance of Heritage Architecture XII

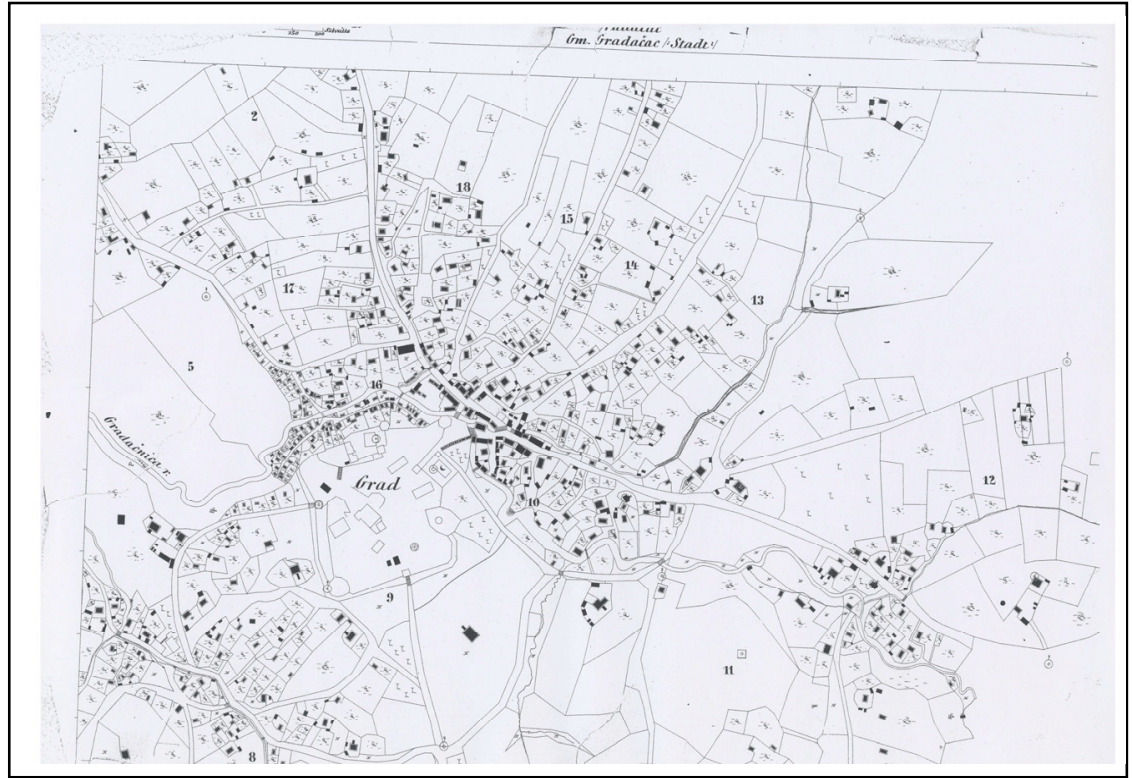

Figure 2: $\quad$ Plan of Gradačac municipality made in the year 1882 year by the Austrian authorities.

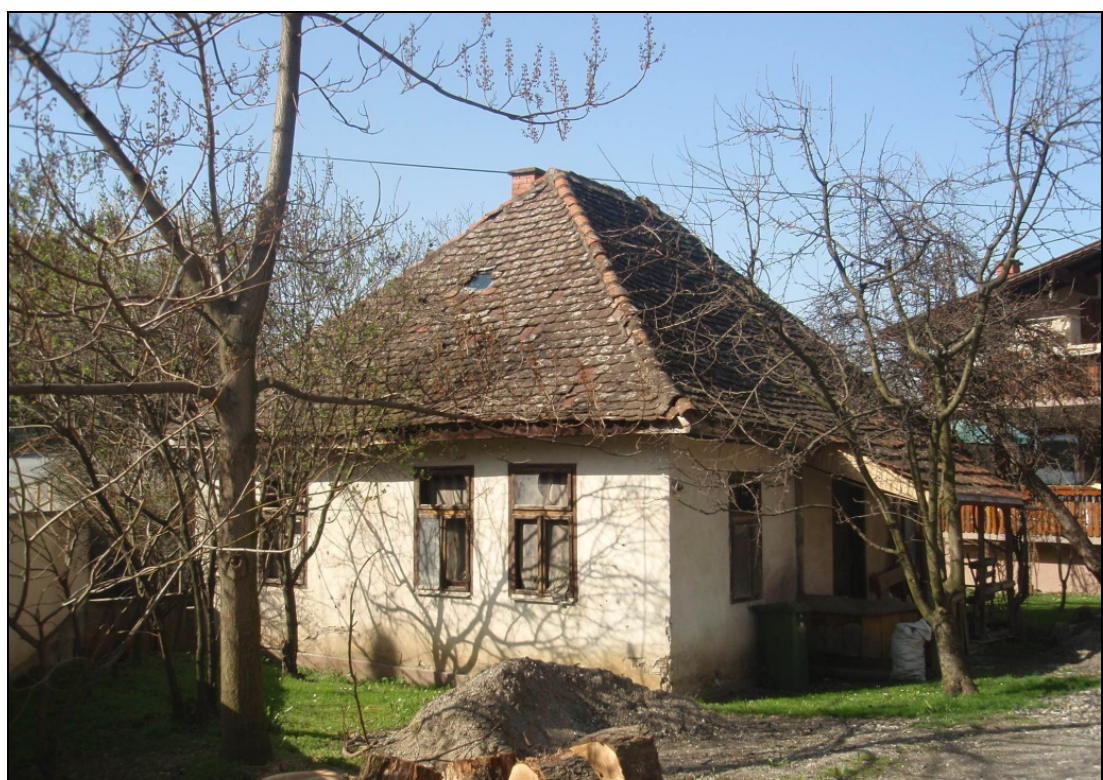

Figure 3: Typical housing structure in Gradacac, an example that still has traditional architectural features. 


\section{Mahala Svirac history [3]}

Most cities were formed in the 15th and 16th century when the empire was on the peak of its power. After establishing the office Gradačac, it rapidly develops an increasing number of inhabitants and sprouts a new mahala. Already in 1785 Gradačac has 111 houses. In the mid 19th century there were about 350 houses, forty stores and shops, two inns, two madrasas, four mosques, and several schools. The village then had seven areas: Svirac, Čaršija, Beech, Kalu, Bagdala, Ciganluk and Serbian mahala. Mahala Svirac had all the elements that made up a typical mahala. In Svirac is the second oldest mosque in Gradacac. Svirac mosque could have been built in the time of Mehmed II Captain between 1756 and 1789 .

\subsection{Mahal Svirac general characteristics}

Mahala Svirac is located on the hillside south of the tower. Looking at the main roads as the axis of development with its left and right sides, it is lined with facilities with central functions: the mosque, fountain, and possibly a bakery. The composition of mahala Svirac was influenced by different factors and by: terrain, roads, vistas, isolation and other local circumstances. Communication within these structures are simple streets, which end as gateways to each house. Architectural structures are the basis for the physical structure of the city, since they are parts that are by their shapes, dimensions and character of the most prominent and most visible part of urban environment. Looking at the architecture of each of these elements, in the mahala we will notice the simplicity of design, and note that the principles are a common feature of all quarters in Bosnia. Housing Construction houses are scattered with a low population density. Gradačačka quarters, including quarters Svirac from their homes, a valuable testament of the time they occur, in all its aspects including the architectural design. Typical Svirac houses are a simple cube measuring $8 \mathrm{~m} \mathrm{x}$ $9 \mathrm{~m}$, with basement floors and an atrium. The contours follow the contours of the floor ground. Floor plans of these houses show simple rooms with a central part that connects them. The rooms are used day and night because this type of house does not recognize the differentiation of public and intimate zones of the house.

The courtyard is a part of the natural environment in a complex of houses, which was characteristic of the Bosnian house at the time. Open and with relatively small dimensions, rectangular and with a uniform rate, they were only a small distance from one another. Hipped roofs were high in accordance with the climate zone. The layout of new houses that now make up the mahala have long since left the Svirac simple form that could be reduced to the rooms and the part that connects the rooms with multi-functional purpose. The whole composition exudes simplicity. All the houses are characterized by clear forms of cubist forms with a modest plastic expression. Each house followed a series of quality standard, so it does not degrade each other in terms of freedom of view, sunlight, neighborhood, etc. With this setting, the houses' urban terrain aspect is its quality, in order to improve the quality of life. 


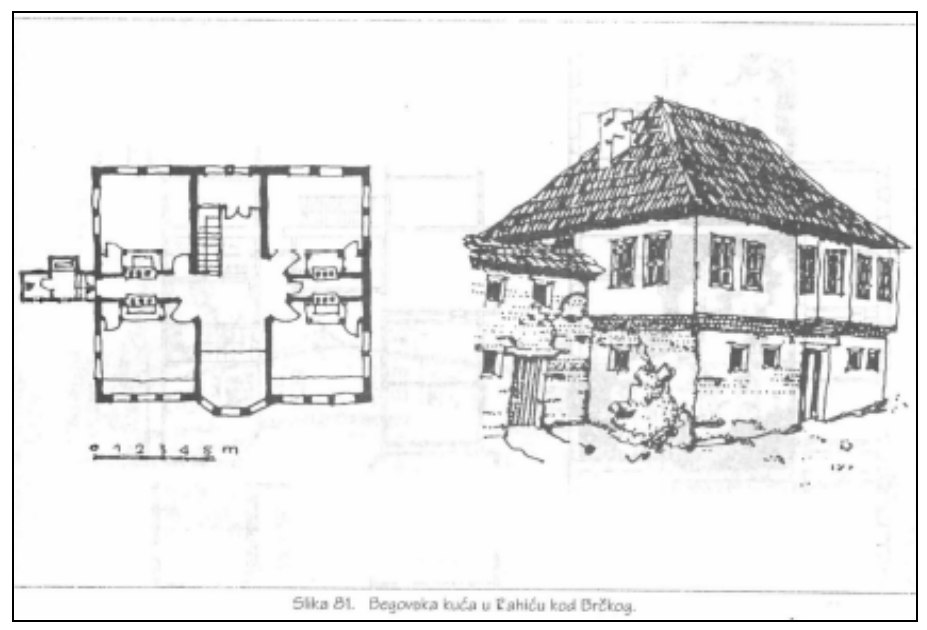

Figure 4: Floor plan and typical architecture of a house from this region, simple multifunctional floor plan and cubic volumes still hold ground as prototypes for the new architectural design.

\subsection{Materials and details}

Using natural materials like local stone and wood, and on upper floors brick, made these houses climate sustainable and easy to maintain, ecofriendly and humane. Resorting to the use of natural materials is typical for this region. The roof cover is of plain clay tiles. Construction of the roof is wood, and the masonry is stone and brick with wood for the ceiling joists. The wall is a floor massively built in relation to the floor. The stone walls are about $50 \mathrm{~cm}$ thick with bonded by lime mortar. Examined samples of the material from the Civil Engineering Institute in Tuzla we came to the conclusion that the stone was extremely strong with the strength of $111.65 \mathrm{MPa}$. This stone was taken from the Gradacac quarry surroundings which stone has such characteristics. Houses were plastered because the masonry was of irregular cut stone. Further testing of material confirmed that it is a lime mortar as it has heated reaction to $\mathrm{HCl}$. The windows are made with a wooden frame, with a single wall in the outer edge wall. Ceilings above the ground floor were made of wooden beams. For stiffening walls wooden beams were used that were affixed to the wall.

\subsection{The present state of mahala Svirac}

By analyzing the physical structure of Svirac we will discover the guidelines and causes, connections and influence of various factors on which the mahala formed and transformed in the present tense. Various social, technical, geomorphological, and economic influences in common, like interaction, gave the picture of mahala Svirac. or what is left of it. Mahala Svirac today is only a name, in the true sense of the words. Colorful images characteristic of 

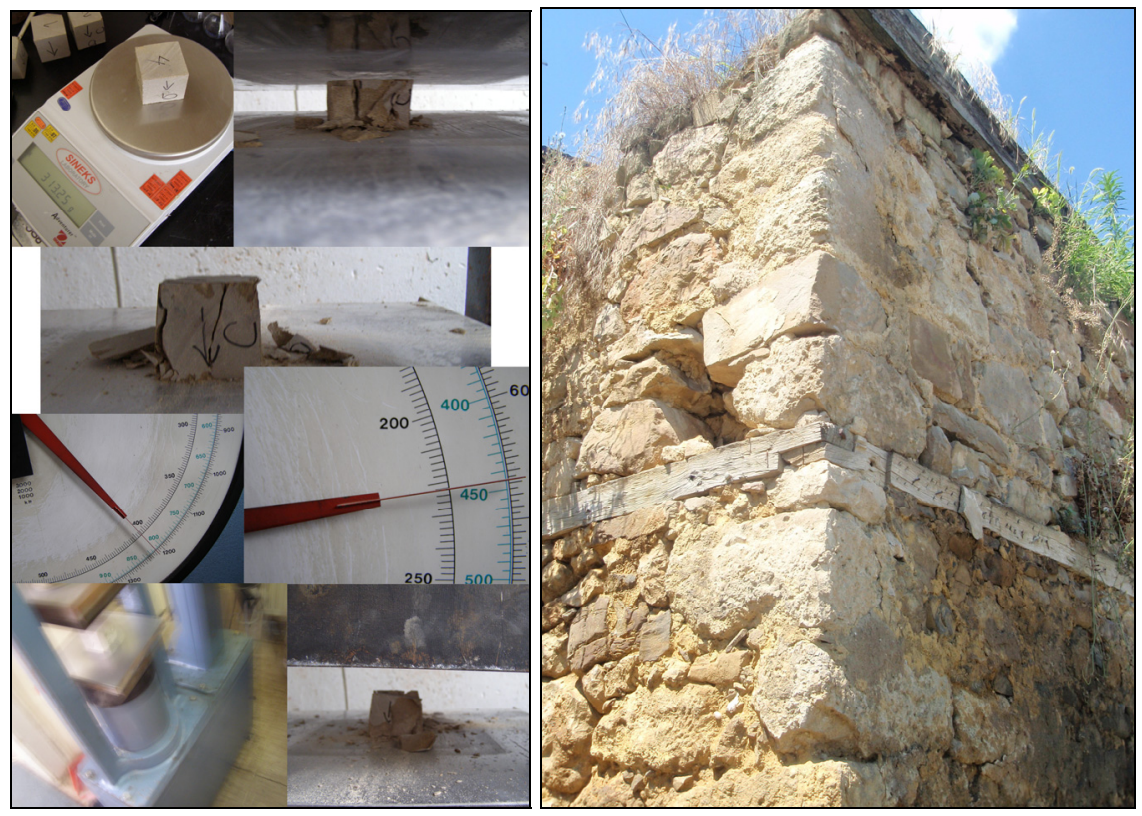

Figure 5: Testing of building materials stones of the local building tradition and detail of the corner wall with wood reinforcement.

architecture are devastated and completely degraded by new construction, which creates a new story without relying on inherited values of structures rooted in local conditions. Degradation is accompanied by an array of new principles that are totally contradictory to traditional principles of a mahala [4]. This is not about criticism of new buildings, but certainly we have to be aware of the value that the past provides as well as space for existence of new objects. The visitor no longer has the feeling that he himself is an integral part of mahala. The old religious complex tombstones are degraded and treated as obsolete, regardless of beauty and design ornaments and motifs that are found on them. Located next to the mosque there are houses that seem to have been built on the open ground without feeling the morphology imposed in its forms, roof pitch, materials and permanently damaging the ensemble. Old houses have been brought to total neglect and decay so that their presence threatens the image of the city, although they used to portray the liveliness of mahala. The idea of reversibility needs to begin with the present situation in order to determine the level of preservation. Because the houses were mostly devastated and neglected, characteristics of these houses can still be found in their footprints on maps and the quality of the building site.

The urban matrix should remain unchanged, but with respect for fundamental characteristic dimensions, levels, volumes, narrow entrances to the houses, woven into the idea that remained legible through simplicity of form, clarity of urban space and ease of physical structures. The physical structure as 
the expression of urban life. Our obligation is to preserve the authentic values of heritage, but certainly we need to determine the levels of intervention to be included in the heritage of modern trends of life and by doing that it is not irreversible and degraded.

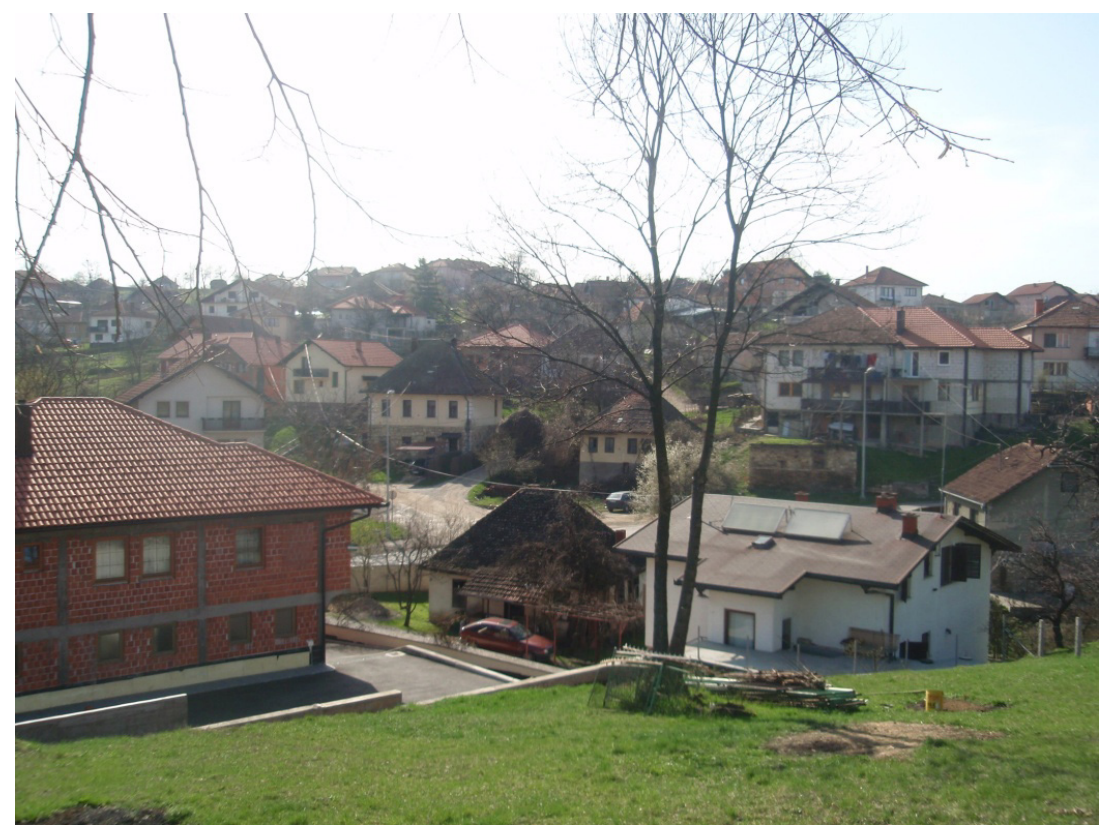

Figure 6: Present condition of the Svirac residential area.

\section{Conclusion}

Preservation of cultural monuments of historical importance should be permanent and should not be left to individuals to decide. Since the fact that the needs and preferences change over time, architectural and urban spaces should be conceived as polyfunctional space, flexible in the long term timeframe, in particular those arising from the legacy of valuable space. In the old quarters, we cannot and do not notice the harmonious relationship between man and environment, harmony, authenticity of form, and content. Weaved in the spatial defines in terms of units, the concept of modern space will be aimed at all levels of functional, economically viable and visually acceptable transformation, adapted to the justified demands of citizens and the modern principles of urban planning space. The overall size of the transformation of the settlement as a legacy is characterized as an irreversible phenomenon. Often the only way to prevent the formation of new construction and inappropriate ones is to make room for the reversible action in these areas not by repetition of forms but by repetition of quality. Today we can only preserve the spirit and immaterial values 
and individual objects but it should be enough to generate new appropriate architecture.

Every building or structure needs to engage in a dialogue with the situation, the past and the particularities of a certain locality in order to be a successful and functional design. It is necessary to explore tangible and intangible components that influence the outcome of the design, and broaden the definitions of context into a process of negotiation with context through different parameters of the urban and architectural features of a mahala. Constant recycling of historic areas is a necessary process that deserves a fresh look each time, but at the same time it deserves our respect. The new approach to design in context allows different (of course contemporary, innovative) approaches that need not apologize for negotiating with the existing architecture.

Mahala, as an integral part of the city, should be a viable structure based on the created and inherited values that will solve the problems that have broken urban and regional development in general and to implement new ways of sustainable urban development. From architecture of regionalism (critical or more direct) we need to stream to architecture of specificity and peculiarity of place, location, and situation. Use of the underlining values of traditional style (not only formal characteristics) can lead into diverse and recognizable architecture of its time and place.

\section{References}

[1] Husref Redžić, Studije o Islamskoj arhitektonskoj baštini, Sarajevo, SOUR Veselin Masleša, 1983

[2] A. Pašić, Islamic Architecture in Bosnia and Hercegovina, Istanbul: IRCICA, 1994

[3] E. Sarajlić, Gradačac sa okolinom u prošlosti, Bošnjačke zajednice kulture "Preporod" Gradačac, 2008

[4] D. Grabrijan., J. Neidthardt, Arhitektura Bosne i put u savremeno, Ljubljana, Državna založba Slovenije, 1957 